\title{
COPPER AND STREPTOMYCIN RESISTANCE IN BACTERIAL STRAINS ISOLATED FROM STONE FRUIT ORCHARDS IN NEW ZEALAND
}

\author{
J.L. VANNESTE ${ }^{1}$, G.F. McLAREN ${ }^{2}$, J. YU ${ }^{1}$, D.A. CORNISH ${ }^{1}$ \\ and R. BOYD ${ }^{1}$ \\ ${ }^{1}$ HortResearch, Ruakura Research Centre, Private Bag 3123, \\ Hamilton, New Zealand \\ ${ }^{2}$ HortResearch, Clyde Research Centre, Alexandra RD1, \\ Central Otago, New Zealand \\ Corresponding author: JVanneste@hortresearch.co.nz
}

\begin{abstract}
Stone fruit orchards in New Zealand are sprayed with copper-based compounds and streptomycin to control bacterial diseases such as bacterial blast (Pseudomonas syringae pv. syringae) and bacterial spot (Xanthomonas arboricola pv. pruni). About $50 \%$ of the bacteria isolated from nectarines from the orchard at Clyde Research Centre, Central Otago, in September 2003, were found to be resistant to copper. The percentage of strains of $P$. syringae pv. syringae isolated in 2004 from nectarines from the same orchard that were resistant to $500 \mathrm{mg} /$ litre of copper was $58 \%$. This percentage rose to $92 \%$ seven days after treating the trees with copper. In 35 of the 48 samples from commercial stone fruit orchards tested, more than half of the bacteria isolated were resistant to $500 \mathrm{mg} /$ litre of copper. Only five strains of Xanthomonas sp. out of the 306 strains tested were resistant to copper; none were resistant to streptomycin.

Keywords: Pseudomonas syringae, Xanthomonas arboricola pv. pruni, Pseudomonas fluorescens, Pantoea agglomerans.
\end{abstract}

\section{INTRODUCTION}

Stone fruit in New Zealand are subject to several bacterial diseases, such as bacterial blast and bacterial spot caused by Pseudomonas syringae pv. syringae and Xanthomonas arboricola pv. pruni respectively. Control of these diseases is mostly limited to treatment with streptomycin and copper-based compounds. Plant pathogenic and plant epiphytic bacteria resistant to copper and/or streptomycin have been isolated from pipfruit orchards in New Zealand (Vanneste \& Voyle 2003). The presence of such resistant strains in stone fruit orchards in this country may limit even further the options available for control of bacterial diseases on stone fruits. Strains of Xanthomonas sp. and strains of P. syringae pv. syringae resistant to copper have been isolated overseas (Cooksey 1990). But there is no report of X. arboricola pv. pruni resistant to copper and most of the strains of $P$. syringae pv. syringae resistant to copper that have been identified were isolated from other plant hosts than stone fruit trees.

The aim of this study was to determine whether strains resistant to copper and/or streptomycin were present in stone fruit orchards in New Zealand. Bacterial strains isolated from samples of stone fruit trees or fruits, obtained from Central Otago and Hawke's Bay, were tested for their resistance to copper and/or streptomycin in the laboratory.

\section{MATERIALS AND METHODS}

Isolation, identification and culture of bacteria in the laboratory

Complete medium was Luria Broth Base (Invitrogen Life Technologies Ltd.); it 
was supplemented with streptomycin (100 ppm) when appropriate. Minimal medium was Ceria 132 (Vanneste et al. 1992). When required it was supplemented with 250 or $500 \mathrm{mg} /$ litre of $\mathrm{CuSO}_{4} \cdot 5 \mathrm{H}_{2} \mathrm{O}$ (BDH Laboratory Supplies). These concentrations reflect the concentration of copper present in treatment suspensions used by the industry for field application. For general bacterial identification King's medium B was used (King et al. 1954). Media specific for Pseudomonas syringae and Xanthomonas spp. were Pseudomonas syringae selective medium and Tween ${ }^{\mathrm{TM}} 80$ hydrolysis medium respectively (Atlas 1997). Cultures were incubated at $28^{\circ} \mathrm{C}$ for $48 \mathrm{~h}$.

Samples consisting of twigs with leaves, flowers or fruits, depending on the time of the year, were couriered from Central Otago or Hawke's Bay to the laboratory in Hamilton. On arrival the samples were washed with 50 to $500 \mathrm{ml}$ of $10 \mathrm{mM} \mathrm{MgSO}_{4}$ depending on the size of the sample. One hundred $\mu \mathrm{l}$ of the washings and/or of different dilutions of the washings made in $10 \mathrm{mM} \mathrm{MgSO}_{4}$ were plated on King's medium B and incubated at $28^{\circ} \mathrm{C}$ for $48 \mathrm{~h}$.

When isolations were made from symptoms on fruits, tissues surrounding the symptoms were cut out with a sterile razor blade and washed by vortexing with 200-300 $\mu \mathrm{l}$ of $10 \mathrm{mM} \mathrm{MgSO}$. One hundred $\mu \mathrm{l}$ of the washings and/or of different dilutions of the washings made in $10 \mathrm{mM} \mathrm{MgSO}_{4}$ were plated on King's medium B and incubated at $28^{\circ} \mathrm{C}$ for $48 \mathrm{~h}$.

The initial identification of bacteria was based on their morphology on King's medium B. This allowed them to be classified as P. syringae, P. fluorescens, Pantoea agglomerans or Xanthomonas spp. Strains were confirmed to be Xanthomonas when they displayed the correct phenotype on selective medium or when they yielded the correct size fragment of DNA after amplification by polymerase chain reaction (PCR). The primers (X16f and X16r) and the cycling conditions used for the PCR experiment were those described by Maes (1993). Confirmation that strains were P. syringae using the specific medium described above was carried out only for samples from commercial orchards. On one occasion, samples received 17 March 2005, the washings and their dilutions were plated directly onto selective media for $P$. syringae or Xanthomonas, or on King's medium B.

For determination of resistance to copper and/or streptomycin, selected bacterial strains were toothpicked individually onto Luria agar (24 strains per plate) and left to grow at $28^{\circ} \mathrm{C}$ for 2 days. They were then transferred onto plates containing copper $(250 \mathrm{mg} /$ litre or $500 \mathrm{mg} /$ litre) or streptomycin using a handheld replicator. The strains $P$. syringae FF5 (Sundin \& Bender 1993) and P. syringae 7B40 (Sundin \& Bender 1996) were used as a negative and a positive control, respectively. Resistance to copper or streptomycin was determined after 2 days incubation at $28^{\circ} \mathrm{C}$.

\section{Collection of samples from the field}

Two experiments were conducted in the orchard at the Clyde Research Centre, Central Otago. In the first experiment, twigs of nectarines cv. Fantasia with open flowers were received on 17 September 2003. The twigs were divided into three categories, depending on the level of copper (high, low or none) that the source trees had received during the late dormant season. Trees that received the high level of copper were treated with Kocide ${ }^{\circledR} 2000$ on 8 August (87.5 g active ingredient/100 litres) and on 26 August (52.5 g ai/100 litres). Trees that received the low level of copper were treated with Kocide ${ }^{\circledR} 2000$ on the same dates with $35 \mathrm{~g}$ ai/100 litres each time. One hundred and twenty bacteria representative of the epiphytic bacteria that could be isolated from twigs of these different categories were selected and assayed for resistance to copper $(250 \mathrm{mg} / \mathrm{litre})$ and streptomycin.

The second field experiment was carried out to establish whether there was a direct link between the use of copper spray and the percentage of copper resistant bacteria. The percentage of copper resistant bacteria present on twigs of Fantasia nectarines was determined before and after treatment with copper. The copper treatment was Kocide $₫$ 2000 at $30 \mathrm{~g} / 100$ litre and was applied 2 November 2004.

A total of 47 samples from commercial orchards in Central Otago were received during 2004/2005. Some blocks were sampled several times during the growing season. 
Samples were from 28 blocks of nectarines, 17 blocks of apricot and two blocks of peaches. Bacterial strains representative of the epiphytic population present on each of the samples were tested for resistance to copper and/or to streptomycin. One sample from a commercial orchard in Hawke's Bay was analysed.

\section{RESULTS}

\section{Copper and streptomycin resistance in the research orchard in Clyde in 2003}

Of the 120 strains tested, nearly half were resistant to copper (Table 1). There tended to be fewer copper-resistant strains on trees that had received no copper than on trees that were treated with high or low levels of copper. Overall, only $10 \%$ of the strains tested were resistant to streptomycin (Table 1). Only five of the 120 strains tested (i.e. $4 \%$ ) were resistant to both copper and streptomycin.

TABLE 1: Number and percentage of bacterial strains resistant to copper or streptomycin isolated from twigs of nectarines cv. Fantasia treated with different rates of copper (high, low or none) at the orchard at Clyde Research Centre.

\begin{tabular}{lcccc}
\hline Strain characteristics & High copper & Low copper & No copper & All categories \\
\hline Resistant to copper & $23 / 46(50 \%)$ & $28 / 50(56 \%)$ & $7 / 24(29 \%)$ & $59 / 120(49 \%)$ \\
Resistant to streptomycin & $2 / 46(4 \%)$ & $4 / 47(8 \%)$ & $4 / 24(17 \%)$ & $12 / 117(10 \%)$ \\
\hline
\end{tabular}

The 120 strains selected for the experiments described above were a mixture of pathogenic and non-pathogenic bacteria. From the original isolation plates, 42 strains of Pseudomonas syringae, as determined by their morphology on King's medium B plates, isolated from the three different categories of samples were assayed for resistance to copper ( $250 \mathrm{mg} / \mathrm{litre})$ and/or streptomycin. Thirty-eight of these $P$. syringae strains $(90 \%)$ were resistant to copper and five $(12 \%)$ were resistant to streptomycin. No strains of Xanthomonas were isolated from this orchard.

Population change in response to copper treatment in 2004

The bacteria selected for this experiment were a mixture of $P$. fluorescens, $P$. syringae and $P$. agglomerans. No strains of Xanthomonas were isolated from this orchard. The percentage of strains of Pseudomonas sp., P. agglomerans (total population) or $P$. syringae resistant to $250 \mathrm{mg} /$ litre of copper rose to $99 \%$ the day following the treatment and stayed at that level up to 7 days after treatment (Table 2). However, the percentage of strains of Pseudomonas sp., P. agglomerans or P. syringae resistant to 500 $\mathrm{mg} /$ litre increased to over $90 \%$ only 7 days after treatment (Table 2). Only $4 \%$ of the total population were resistant to both copper and streptomycin before copper treatment. This percentage went down to $2 \%$ seven days after treatment.

TABLE 2: Number and percentage of strains of different Pseudomonas sp. and $P$. agglomerans (total population) or of $P$. syringae resistant to 250 or $500 \mathrm{mg} /$ litre of copper. Bacteria were isolated from twigs of nectarine from the orchard at Clyde Research Centre before and after treatment with copper.

\begin{tabular}{|c|c|c|c|}
\hline \multirow[b]{2}{*}{ Timing } & \multicolumn{2}{|c|}{$\begin{array}{c}\text { Resistant to copper at } \\
250 \mathrm{mg} / \text { litre }\end{array}$} & $\begin{array}{l}\text { Resistant to copper at } \\
500 \mathrm{mg} / \text { litre }\end{array}$ \\
\hline & Total population & P. syringae & Total population P. syringae \\
\hline Before treatment & $71 / 76(93 \%)$ & $40 / 45(89 \%)$ & $52 / 76(68 \%) \quad 26 / 45(58 \%)$ \\
\hline 1 day after treatment & $119 / 120(99 \%)$ & $95 / 96(99 \%)$ & $91 / 120(76 \%)$ \\
\hline 7 days after treatment & $119 / 120(99 \%)$ & $71 / 72(99 \%)$ & $113 / 120(94 \%) \quad 66 / 72(92 \%)$ \\
\hline
\end{tabular}




\section{Resistance in commercial orchards in Central Otago and in Hawke's Bay}

In 42 of the 47 samples from Central Otago orchards, more than $50 \%$ of the bacteria tested were resistant to copper at a concentration of $250 \mathrm{mg} /$ litre. Furthermore, in 35 of the 47 samples tested, more than $50 \%$ of the bacteria were resistant to copper at a concentration of $500 \mathrm{mg} /$ litre. In 33 samples more than half the bacteria tested were streptomycin resistant.

Xanthomonas was isolated only from nine blocks of nectarines, four blocks of apricots and one block of peaches out of the 47 blocks sampled. A total of 306 strains were isolated. Five of those strains, all isolated from the same commercial orchard of nectarines, grew on medium supplemented with copper at a concentration of $250 \mathrm{mg} /$ litre and four of these strains were able to grow on medium supplemented with copper at a concentration of $500 \mathrm{mg} /$ litre. No strains of Xanthomonas tested were resistant to streptomycin.

Of the 120 bacteria selected from the Hawke's Bay orchard, $67 \%$ were resistant to copper at a concentration of $250 \mathrm{mg} / \mathrm{litre}, 46 \%$ to copper at $500 \mathrm{mg} / \mathrm{litre}$ and $97 \%$ to streptomycin.

\section{DISCUSSION}

Copper-based compounds and streptomycin are the only two types of compounds available for control of bacterial diseases. Plant pathogenic and plant epiphytic bacteria resistant to either or both of these compounds have previously been isolated from pipfruit orchards in the Hawke's Bay area (Vanneste \& Voyle 2003). This study indicates that similar strains are also present in stone fruit orchards in Hawke's Bay and Central Otago. However, no strains of Xanthomonas spp. isolated during this project were resistant to streptomycin and only five strains isolated from one commercial orchard were resistant to copper. The species and pathovar of these strains have not been identified yet. If these strains are identified as $X$. arboricola pv. pruni, this would be the first report of strains of this pathovar being resistant to copper.

The use of copper-based compounds seems to increase the percentage of strains that are resistant to copper. In the block of Fantasia nectarines from the orchard at Clyde Research Centre that did not receive copper treatment during the dormant period of 2003, the percentage of strains resistant to copper was lower than in the two other blocks. In 2004, the percentage of copper resistant strains before treatment with copper was relatively high (58\% to $93 \%$ ), but it was even higher after treatment with copper (76\% to 99\%). Furthermore, the fact that the percentage of copper resistant bacteria was relatively high before the copper treatment could simply reflect that the block used in that experiment had received two copper treatments in August 2004. The block also had a history of copper usage over its 25 years since being in pasture.

Although the results from the commercial orchards from Central Otago do not represent a survey of copper resistance in stone fruit orchards in New Zealand, they indicate that the presence of strains of $P$. fluorescens, $P$. syringae and $P$. agglomerans resistant to copper and/or streptomycin is not limited to the orchard at the Clyde Research Centre. A survey that would establish the spread and the nature of copper resistance in plant associated bacteria (pathogens and epiphytes) isolated from stone fruit orchards, is necessary for the development of a management strategy for copper resistance and for the development of recommendations on the use of copper-based compounds for control of bacterial diseases on stone fruit in New Zealand.

\section{Note added in proof}

Recent further analyses indicate that the five strains initially described as being strains of Xanthomonas sp. resistant to copper do not share all characteristics of strains that belong to that genus. Their classification as strains of Xanthomonas sp. is being reviewed.

\section{ACKNOWLEDGMENTS}

This project was partly funded by Summerfruit New Zealand. Thanks to Ross Marshall, HortResearch, Clyde Research Centre, for applying the trial treatments. 


\section{REFERENCES}

Atlas RM 1997. Handbook of Microbiological Media 2nd edition. Park LC ed. CRC Press Inc., Boca Raton, New York, London, Tokyo. 1706 p.

Cooksey DA 1990. Genetics of bactericide resistance in plant pathogenic bacteria. Annual Review of Phytopathology 28: 201-219.

King EO, Ward MK, Raney DE 1954. Two simple media for the demonstration of pyocyanin and fluorescin. Journal of Laboratory Clinical Medicine 44: 301-307.

Maes M 1993. Fast classification of plant-associated bacteria in the Xanthomonas genus. FEMS Microbiology Letters 113(2): 161-165.

Sundin GW, Bender CL 1993: Ecological and genetic analysis of copper and streptomycin resistance in Pseudomonas syringae pv. syringae. Applied and Environmental Microbiology 59: 1018-1024.

Sundin GW, Bender CL 1996. Molecular analysis of closely related copper- and streptomycin- resistance plasmids in Pseudomonas syringae pv. syringae. Plasmid 35: 98-107.

Thomson SV, Gouk SC, Vanneste JL, Hale CN, Clark RG 1993. The presence of streptomycin resistance in pathogenic and epiphytic bacteria isolated in apple orchards in New Zealand. Acta Horticulturae 489: 671-672.

Vanneste JL, Voyle MD 2001. Characterisation of transposon, genes, and mutations which confer streptomycin resistance in bacterial strains isolated from New Zealand orchards. Acta Horticulturae 590: 493-495.

Vanneste JL, Yu J, Beer SV 1992. Role of antibiotic production by Erwinia herbicola Eh252 in biological control of Erwinia amylovora. Journal of Bacteriology 174: 2785-2796. 